\title{
Effect of Mono Treatment and Combined Treatment on the Morphology of Myco. leprae in the Skin
}

\author{
D. L. LEIKER \\ Royal Tropical Institute, Amsterdam
}

A study is made of the effect of clofazimine, of rifampicin, of a combination of rifampicin with isoniazid and sulphamethoxy-pyrazinamide and of a combination of rifampicin with tri-methoprim-sulphonamide and prothionamide, on the morphology of Myco. leprae in foamy cells, in arrectores pilorum muscles, in blood vessel walls, and in nerves in the skin of patients with lepromatous leprosy. The method of assessment was by blind examination of serial biopsies, taken each time from the same lesion.

At the onset of the trial the percentage of granular bacilli was, on the average, $14.3 \%$ lower in blood vessel walls, $8.3 \%$ lower in arrector pilorum muscle and $8.1 \%$ lower in nerves, than it was in foamy cell infiltrates. Occasionally higher percentages of granular bacilli were found in muscle or nerve, and this was related to previous treatment.

After 1-3 months of treatment, with all drug regimens, the percentages of granular bacilli increased markedly, not only in the foamy cell infiltrates, but also proportionally in smooth muscle and nerve.

After 1-2 years of treatment in most patients all or nearly all bacilli had become granular, with no significant differences between the percentages in foamy cell infiltrates, smooth muscle and nerve.

The effect of clofazimine was slower than of the other drug regimens.

No significant difference was found between the group of patients treated with rifampicin and those treated with a combination of rifampicin with other drugs. The finding of 99\% granular bacilli in several patients treated for 1-2 years indicates that none of the drug regimens had produced complete clearance of viable bacilli. Even if only $1 \%$ of the non granular bacilli is viable, in a lepromatous patient with a load of bacilli of $10^{10}$, a granularity index of $99 \%$ means that $10^{6}$ viable bacilli are still present.

The method used is not regarded as sufficiently sensitive for excluding the possibility that even in patients with counts of $100 \%$ granular bacilli complete clearance of viable bacilli has been achieved. The rapid and good response of bacilli in muscle and nerve in the skin to all drug regimens suggests that these sites are not the only or the most important sites of therapy-resistant bacilli. Other sites, e.g. large peripheral nerves, bone marrow and internal organs should be investigated. One patient treated with the combination supposed to have the highest bacteriocidal activity (rifampicin-eusaprim-ethionamide), absconded after 4 months of treatment and relapsed after a period of 2 years without treatment, indicating that not all viable bacilli were eliminated. In this patient in a biopsy of an old lesion large numbers of bacilli were present, but all bacilli were granular, whereas in the new relapse lesions a high percentage of non-granular bacilli was found. This suggests that the relapse was not due to survival of bacilli in old skin lesions, but to therapy resistant bacilli at other sites. 


\section{Introduction}

The presence of Myco. leprae in the smooth muscle of blood-vessels was first reported by Nishiura (1960) and the presence of Myco. leprae in arrectores pilorum muscles was reported by Neves (1961). Harman (1968) found that Myco. leprae in smooth muscles may stain less irregularly than the bacilli in the surrounding infiltrate. Leiker (1969) had found in skin biopsies morphologically intact bacilli in smooth muscle in treated lepromatous patients long after all bacilli in smears had become granular, occasionally even after smears had become bacteriologically negative. It was thought that these bacilli might be the origin of relapses.

It was also noticed that the bacilli located within smooth muscle cells do not elicit a reticulo-endothelial cellular response, in contrast with the interstitial myositis seen in some lepromatous patients. The absence of a lymphocytic reaction suggests immunological incompetence. It is possible that the bacilli are only very feebly metabolically active and that therefore drugs which normally interfere with metabolic processes do not effect the "dormant" bacilli (Leiker, 1971). In a previous article (Leiker et al., 1973) the effect of rifampicin and a combination of rifampicin with other drugs on the Bacterial Index (BI) was compared. No significant difference was found. The BI decreased by about $1+$ per year with both regimens. In the present study of 4 groups of patients with different drug regimens a comparison is made of the morphology of Myco. leprae in foamy cell infiltrates, smooth muscle tissue of arrectores pilorum muscles and blood-vessel walls, and in nerve twigs in the skin.

\section{Material}

Group I consisted of 6 lepromatous patients treated with clofazimine, to begin with $100 \mathrm{mg}$ daily, in some patients followed by $100 \mathrm{mg}$ every second day.

Group II consisted of 7 lepromatous patients treated with $600 \mathrm{mg}$ rifampicin daily.

Group III consisted of 7 lepromatous patients treated with $600 \mathrm{mg}$ rifampicin, $400 \mathrm{mg}$ isoniazid and $200 \mathrm{mg}$ sulfamethoxypyrazine daily (triple I).

Group IV consisted of 4 lepromatous patients treated with $600 \mathrm{mg}$ rifampicin, $1000 \mathrm{mg}$ trimethoprim-sulfonamide (eusaprim) and $250 \mathrm{mg}$ ethionamide or prothionamide daily (triple II). Freerksen had found that in mouse experiments with Myco. marinum these combinations of drugs were more active than the single drugs alone. All patients were highly bacilliferous lepromatous patients with BI $6+$ and with at least $20 \%$ non-granular bacilli at the onset of the trial.

\section{Method}

In each patient serial biopsies were taken each time from the same skin lesion. The Granularity Index (GI) was calculated by one investigator. All readings were made blindly.

Because it is less difficult to distinguish between granular and fragmented bacilli than between completely solidly stained and slightly fragmented bacilli, the percentage of granular bacilli (GI), instead of the percentage of solid bacilli (MI) was recorded. 


\section{Results}

In some biopsies no arrectores pilorum muscle was present and in others no bacilli were found in the muscle. In sections from biopsies taken at the onset of the trial of the 12 patients, however, bacilli were present in arrectores pilorum muscle, blood-vessel wall and nerve, in addition to bacilli in foamy cell infiltrates. In half of these patients the GI in the first 3 tissues was on the average $25 \%$ lower as compared with the foamy cell infiltrates. In 2 other patients on the average $14 \%$ less granular bacilli were seen in blood-vessel wall and nerve, but $11 \%$ more granular bacilli in arrectores pilorum muscle. In 1 other patient $14 \%$ less granular bacilli were found in blood-vessel wall, but $31 \%$ more granular bacilli in arrectores pilorum muscle and nerves. In the remaining 3 patients the granularity index was on the average $9 \%$ lower in the infiltrates as compared with the other tissues. In all 12 patients the average GI was $14.3 \%$ lower in blood-vessel wall, $8.3 \%$ lower in arrectores pilorum muscle, and $8.1 \%$ lower in nerve, as compared with foamy cell infiltrates. These figures confirmed that in general higher percentages of non granular bacilli are found in smooth muscle and nerves but also that there are exceptions, probably related to previous treatment.

In the group of patients treated with Lamprene (Table 1), after 3-6 months of treatment the GI in all patients had significantly increased. The increase in GI was seen in the foamy cells as well as in smooth muscle and nerve tissue. Three out of 6 patients, however, failed to reach a high GI; not only in muscle and nerve, but also in foamy cells.

After 1-2 years of treatment in nearly all patients the GI had reached $100 \%$ or nearly $100 \%$. In only 1 patient (no. 3) a significant number of non granular bacilli was found in blood-vessel wall after 2 years of treatment.

In the group of patients treated with rifampicin (Table 2), after 3 months of treatment all patients but 1 showed a high granularity index in foamy cells as well as in the other tissues. In 1 patient presenting low GI's the treatment had been temporarily interrupted. The effect of rifampicin on the morphology of Myco. leprae was more rapid than that of clofazimine, as expected. Af ter 12-24 months of treatment in nearly all patients the GI reached $100 \%$ or nearly $100 \%$, in foamy cells as well as in smooth muscle and nerves.

In the group of patients treated with triple combination I (Table 3), after 3 months of treatment 2 out of 7 patients, and after 9 months of treatment 1 out of 7 patients still showed a relatively low GI. After 1-2 years of treatment in all patients the GI had become $100 \%$ or nearly $100 \%$, in foamy cells and in smooth muscle and nerves. No significant difference was found between this group and the group of patients treated with rifampicin alone.

In the group of patients treated with triple combination II (Table 4), after 3 months of treatment in all patients the GI had reached $100 \%$ or nearly $100 \%$. There is no significant difference with the group of patients treated with rifampicin alone.

One patient of group 4, after a period of 4 months of treatment, absconded and was seen again after a period of nearly 2 years without treatment, with a clinical and bacteriological relapse.

In this patient, male, 46, lepromatous leprosy with a Mitsuda reaction of $0 \mathrm{~mm}$, treatment was started in 1962 with 600 mg DDS weekly for 1 year, followed by $400 \mathrm{mg}$ DDS weekly for 4 years, $600 \mathrm{mg}$ DDS for 2 years and $400 \mathrm{mg}$ DDS weekly for 1 year. The BI decreased from $6+$ in 1962 , to $<1+$ in 1968 and in 
TABLE 1

Effect of Lamprene $100 \mathrm{mg}$ daily to $100 \mathrm{mg}$ every second day on morphology of Myco. leprae

\begin{tabular}{|c|c|c|c|c|c|c|c|c|c|c|c|c|c|c|c|c|c|c|c|c|c|c|c|c|}
\hline \multirow[b]{2}{*}{$\begin{array}{l}\text { Months of } \\
\text { treatment }\end{array}$} & \multicolumn{6}{|c|}{ GI in infiltrates } & \multicolumn{6}{|c|}{ GI in $\mathrm{M}$ arrectores pilorum } & \multirow{2}{*}{\multicolumn{6}{|c|}{$\begin{array}{l}\text { GI in blood-vessel muscle } \\
\text { Patient no. }\end{array}$}} & \multirow{2}{*}{\multicolumn{6}{|c|}{$\begin{array}{l}\text { GI in nerves } \\
\text { Patient no. }\end{array}$}} \\
\hline & 1 & 2 & $\begin{array}{c}\text { Patie } \\
3\end{array}$ & $\begin{array}{c}\text { nt no. } \\
4\end{array}$ & 5 & 6 & 1 & 2 & $\begin{array}{c}\text { Patie } \\
3\end{array}$ & $\begin{array}{l}\text { no. } \\
4\end{array}$ & 5 & 6 & & & & & & & & & & & & \\
\hline $\begin{array}{l}0 \\
1 \\
2\end{array}$ & 45 & 19 & 9 & 54 & 25 & 45 & & 46 & 17 & 80 & 33 & 42 & 14 & 16 & 3 & 19 & 11 & 13 & & & & 16 & 80 & \\
\hline $\begin{array}{l}3 \\
6\end{array}$ & $\begin{array}{l}81 \\
98\end{array}$ & 100 & 69 & $\begin{array}{l}96 \\
94\end{array}$ & $\begin{array}{r}100 \\
94\end{array}$ & 90 & & 97 & 68 & 94 & & 84 & $\begin{array}{l}76 \\
96\end{array}$ & 94 & 64 & $\begin{array}{l}94 \\
90\end{array}$ & 93 & 76 & & & & & & 74 \\
\hline 9 & 98 & 100 & 97 & & 99 & 100 & & 97 & 93 & & & 94 & 100 & 100 & 91 & & 93 & 99 & & & 99 & & 96 & 94 \\
\hline 12 & 100 & & 98 & 97 & 97 & 100 & & & 79 & & 98 & 99 & 100 & & & 96 & 95 & 100 & & & 87 & & & \\
\hline 18 & 100 & 98 & & 100 & & & & & & 99 & 99 & & 99 & & & 99 & & & & & & & 100 & \\
\hline 24 & 99 & 100 & 98 & 100 & 97 & 100 & & & & & 99 & & 99 & & 87 & 100 & 100 & & & & & & & \\
\hline
\end{tabular}

GI $=$ Granularity Index.

TABLE 2

Effect of rifampicin $600 \mathrm{mg}$ daily on morphology of Myco. leprae

\begin{tabular}{|c|c|c|c|c|c|c|c|c|c|c|c|c|c|c|c|c|c|c|c|c|c|c|c|c|c|c|c|}
\hline \multirow{3}{*}{$\begin{array}{l}\text { Months of } \\
\text { treatment }\end{array}$} & \multicolumn{7}{|c|}{ GI in infiltrates } & \multicolumn{7}{|c|}{$\mathrm{GI}$ in $\mathrm{M}$ arrectores pilorum } & \multicolumn{7}{|c|}{ GI in blood-vessel muscle } & \multicolumn{6}{|c|}{ GI in nerves } \\
\hline & \multicolumn{7}{|c|}{ Patient no. } & \multicolumn{7}{|c|}{ Patient no. } & \multicolumn{7}{|c|}{ Patient no. } & \multicolumn{6}{|c|}{ Patient no. } \\
\hline & 1 & 2 & 3 & 4 & 5 & 6 & 7 & 1 & 2 & 3 & 4 & 5 & 6 & 7 & 1 & 2 & 3 & 4 & 5 & 6 & 7 & 1 & 2 & 3 & 5 & 6 & 7 \\
\hline 0 & 44 & 39 & 22 & 65 & 51 & 41 & 41 & 51 & & 18 & 68 & 53 & 36 & 55 & 40 & 26 & 14 & 73 & 70 & 40 & 47 & 40 & & 80 & 58 & 32 & 50 \\
\hline 1 & 85 & 88 & 99 & 97 & 89 & 80 & 77 & 67 & 67 & & 94 & 97 & 87 & 79 & 61 & 79 & & 91 & 99 & 96 & 71 & 51 & & 97 & 98 & 62 & 67 \\
\hline 2 & & & & 97 & 99 & & & & & & 98 & 100 & & & & & & 99 & 99 & & & & & 96 & 100 & & \\
\hline 3 & 92 & 95 & & 94 & 99 & 100 & $70^{a}$ & & 96 & & 100 & 100 & 100 & $85^{a}$ & 93 & 94 & & 98 & 99 & 100 & $74^{a}$ & & & 100 & 99 & 97 & $76^{a}$ \\
\hline 6 & 100 & 82 & & 100 & 99 & 99 & 100 & 100 & 99 & & & 100 & 100 & 95 & 100 & 97 & & & 100 & 100 & 100 & & & & 100 & 100 & 100 \\
\hline 9 & 100 & 99 & & & 100 & 94 & 99 & 100 & & & 100 & 99 & 99 & 98 & & & & 100 & 100 & 100 & 100 & & & 100 & 100 & 100 & 99 \\
\hline 12 & 100 & 100 & 97 & 100 & 97 & 99 & 100 & 100 & & 100 & 100 & 99 & 100 & 100 & 100 & 100 & 100 & 100 & 99 & 100 & 100 & 100 & 100 & 100 & 100 & 100 & 100 \\
\hline 18 & 97 & 94 & & 100 & 100 & 99 & 98 & 100 & 100 & & 100 & 100 & 100 & 98 & 100 & 100 & & 100 & 100 & 100 & 100 & 100 & 100 & 100 & 99 & 100 & 99 \\
\hline 24 & & 100 & 99 & & 100 & 99 & 100 & & 100 & 100 & & 100 & 100 & 100 & & & 100 & & 100 & 100 & 100 & 100 & 100 & & 100 & 100 & 100 \\
\hline
\end{tabular}

GI = Granularity Index

$a$ Treatment interrupted. 
TABLE 3

Effect of triple I treatment on morphology of Myco. leprae

\begin{tabular}{|c|c|c|c|c|c|c|c|c|c|c|c|c|c|c|c|c|c|c|c|c|c|c|c|c|c|c|c|c|}
\hline \multirow{3}{*}{$\begin{array}{l}\text { Months of } \\
\text { treatment }\end{array}$} & \multicolumn{7}{|c|}{ GI in infiltrates } & \multicolumn{7}{|c|}{$\mathrm{GI}$ in $\mathrm{M}$ arrectores pilorum } & \multicolumn{7}{|c|}{ GI in blood-vessel muscle } & \multicolumn{7}{|c|}{ GI in nerves } \\
\hline & \multicolumn{7}{|c|}{ Patient no. } & \multicolumn{7}{|c|}{ Patient no. } & \multicolumn{7}{|c|}{ Patient no. } & \multicolumn{7}{|c|}{ Patient no. } \\
\hline & 1 & 2 & 3 & 4 & 5 & 6 & 7 & 1 & 2 & 3 & 4 & 5 & 6 & 7 & 1 & 2 & 3 & 4 & 5 & 6 & 7 & 1 & 2 & 3 & 4 & 5 & 6 & 7 \\
\hline 0 & 40 & 78 & 51 & 39 & 26 & 23 & 29 & 5 & & & & 76 & & & 9 & 85 & & 17 & & 22 & & 16 & & & & & & \\
\hline 1 & 76 & 95 & 99 & 88 & 52 & & 92 & & & & 95 & & & & 19 & 95 & & 93 & & & & 24 & & & 87 & & & \\
\hline 2 & & & & 96 & 59 & 93 & & & & & 100 & 74 & & & & & & 98 & 82 & 97 & & & & & 100 & & & \\
\hline 3 & 74 & 98 & 95 & 82 & & 98 & 95 & 44 & & 84 & 100 & & & & 88 & & & 100 & & & & & & & 98 & & 98 & 99 \\
\hline 6 & 98 & 96 & 92 & 95 & & 97 & & & & & 100 & & & & 100 & & & 100 & & 98 & & 100 & & & & & & \\
\hline 9 & 95 & 99 & 92 & 96 & 78 & 97 & 100 & & & 98 & & 70 & & & 99 & & 98 & 99 & 89 & & & & & 97 & 100 & & 99 & 100 \\
\hline 12 & 99 & 96 & 100 & 95 & 100 & 100 & 99 & 100 & & 99 & 100 & 98 & & & 92 & & 97 & 100 & 96 & 97 & & 99 & & 98 & 98 & & & 99 \\
\hline 18 & 98 & 99 & 99 & 99 & 99 & 99 & 99 & 99 & & 99 & & 98 & & 98 & 100 & & 100 & 94 & 98 & 92 & 98 & 100 & & 98 & & & & 96 \\
\hline 24 & 100 & 100 & 99 & & & 99 & & & & 89 & & & & & 98 & & 99 & & & & & & & 100 & & & & \\
\hline
\end{tabular}

GI = Granularity Index.

TABLE 4

Effect of triple II treatment on morphology of Myco. leprae

\begin{tabular}{|c|c|c|c|c|c|c|c|c|c|c|c|c|c|c|c|c|}
\hline \multirow{3}{*}{$\begin{array}{l}\text { Months of } \\
\text { treatment }\end{array}$} & \multicolumn{4}{|c|}{ GI in infiltrates } & \multicolumn{4}{|c|}{ GI in $\mathrm{M}$ arrectores pilorum } & \multicolumn{4}{|c|}{ GI in blood-vessel muscle } & \multicolumn{4}{|c|}{ GI in nerves } \\
\hline & \multicolumn{4}{|c|}{ Patient no. } & \multicolumn{4}{|c|}{ Patient no. } & \multicolumn{4}{|c|}{ Patient no. } & \multicolumn{4}{|c|}{ Patient no. } \\
\hline & 1 & 2 & 3 & 4 & 1 & 2 & 3 & 4 & 1 & 2 & 3 & 4 & 1 & 2 & 3 & 4 \\
\hline 0 & 28 & 65 & 53 & 40 & 13 & 20 & 26 & 8 & 10 & 19 & 10 & 27 & 9 & 12 & 39 & 29 \\
\hline 1 & 100 & & & 82 & 91 & & & 52 & 98 & & & 86 & 98 & & & 70 \\
\hline 2 & & 100 & 98 & 99 & & 98 & 96 & 95 & & 97 & 85 & 97 & & 99 & 94 & 99 \\
\hline 3 & 100 & & 99 & 97 & 94 & & 98 & & 99 & & 92 & & & & 98 & \\
\hline 6 & & 99 & & 100 & & 100 & & 95 & & 96 & & & & 100 & & 100 \\
\hline 9 & 100 & & & & 100 & & & & 100 & & & & 98 & & & \\
\hline 12 & & & & 100 & & & & 100 & & & & 99 & & & & 100 \\
\hline
\end{tabular}

$\mathrm{GI}=$ Granularity Index. 
1969 no bacilli were found in a biopsy specimen. In 1971 a clinical and bacteriological relapse was seen, thought to be due to sulphone resistance. This was confirmed by mouse footpad tests.

Treatment was resumed with $600 \mathrm{mg}$ rifampicin daily combined with $1 \mathrm{~g}$ eusaprim and $500 \mathrm{mg}$ ethionamide daily. After 2 months of treatment the GI had increased from $47 \%$ to $98 \%$ and after 4 months of treatment to $99 \%$. Thereafter the patient absconded and no treatment was taken. Two years later, after relapse of the disease, 2 biopsy specimens were taken, 1 from an old lesion and 1 from a new lesion. In the first specimen a high BI was found, but all bacilli were granular. In the second specimen a high BI was found as well, but a high percentage of the bacilli were non granular.

\section{Discussion}

The results obtained after 12-24 months of treatment show that all drug regimens are not only active on bacilli in foamy cells, but also on bacilli in smooth muscle and nerves. Apparently most bacilli in these tissues are less "dormant" than it has been assumed.

Apart from a slight delay in increase in GI's in smooth muscle and nerve, as compared with foamy cells, the morphological changes are correlated. After 1-2 years with all drug regimens in nearly all patients and at all sites investigated the GI had reached $100 \%$ or nearly $100 \%$. In all groups however, a few patients showed a GI of slightly less than $100 \%$. If in a lepromatous patient with a bacterial load of $10^{10}$ bacilli, the granularity index is $99 \%$, and if only $1 \%$ of the non-granular bacilli are viable, it means there are still $10^{6}$ viable bacilli present.

The relapse seen in a patient treated with triple combination II shows that a short course certainly is not sufficient for eliminating all viable bacilli. The fact that after 1-2 years of treatment with rifampicin or with the combination of rifampicin with other drugs in some patients still 1-2\% non-granular bacilli were found, indicates that even after 1-2 years viable bacilli may still be present.

The method of assessment, apart from being very time consuming, is not regarded as sufficiently sensitive for accurate evaluation of the sterilizing effect of drugs. Even if in all sections of a biopsy specimen, in foamy cell infiltrates, smooth muscle and nerves $100 \%$ granularity of the bacilli is found, the presence of persistent viable bacilli at other sites is not excluded.

The rapid increase in the percentage of granular bacilli in smooth muscle and nerves in the skin seen after treatment with all drugs and drug combinations, and the absence of non granular bacilli in a biopsy specimen of an old highly bacilliferous lesion in the patient who relapsed, suggest that the skin may not be the most important site where therapy resistant bacilli survive. Other sites, e.g. large peripheral nerves, bone marrow may be equally if not more important and deserve further investigations.

\section{References}

Harman, D. J. (1968). Mycobacterium leprae in muscle, Lepr. Rev. 39, 197.

Leiker, D. L. (1969). The problem of concealed bacilli in treated leprosy patients. Scientif. Conf. on Mycobacterial and Related Diseases, Dar es Salaam.

Leiker, D. L. (1971). Chemotherapy of leprosy, Int. J. Lepr. 39-2, 462.

Leiker, D. L., Verhagen, A. R. (1973). Assessment of the bacteriological effect of combined treatment with rifadin, sulfamethoxypyrazine and isoniazide in lepromatous leprosy, $Z$. Tropenmed. Parasit. 24, 32. 
Neves, R. G. (1961). O mycobacterium leprae no musculo erector dopelo, Bol. Serv. Nac. Lepr. 20,17

Nishiura, M., Sirsat, S. M., Khanolkar, V. R. (1960). Electron microscopic study of leprosy lesion, Lepr. India 32-90. 